\title{
On Glaucocystis Nostochinearum, Itzigsohn.
}

\author{
BY
}

\author{
B. MILLARD GRIFFITHS, M.Sc.
}

\section{With Plate XIX.}

G LAUCOCYSTIS NOSTOCHINE ARUM, Itzigs., is a unicellular solitary alga found generally in Sphagnum-bogs. It is ellipsoidal in form and measures from 30 to $45 \mu$ in length, and from $I 8$ to $25 \mu$ in breadth. It has a chromoplast consisting of a number of strongly recurved radiating bands of a blue green colour. It reproduces by the formation of two, four, or eight daughter-cells within the mother-cell.

The systematic position of the organism has been doubtful. Chodat placed it in the Protococcaceae owing to its resemblance to Oocystis (vide Oltmanns, '04). Oltmanns can find no certain place for it, but refuses to put it in the Protococcaceae owing to its blue-green colour. West ('04) classifies it among the Cyanophyceae (or Myxophyceae). He divides the whole group into Glaucocystideae and Archiplastideae, and therefore places Glaucocystis outside the rest of the Cyanophyceae. The difficulty of assigning it to a definite group is intensified by conflicting evidence regarding its nucleus. Lagerheim states that the nucleus is merely a vacuole (Hieronymus, '92). Hieronymus describes a perfectly definite nucleus containing a body resembling a nucleolus.

I found the organism in considerable quantities at the beginning of the year I9ro, and with this material at my disposal have carefully examined the nucleus with a view to discovering its exact nature. The investigation was suggested by Professor G. S. West in order to obtain further information concerning its cytology with a view to determining the systematic position of the organism. The results show that Glaucocystis is one of the Cyanophyceae, but with a nuclear structure of much greater definiteness than is found in the rest of the group, and possessing many features that make it almost comparable with the more highly elaborated nucleus of higher plants.

The organism occurred in a small permanent surface-water pool near Kidderminster, Worcs., among the lower portions of a dense growth of Fontinalis antipyretica. It was found at all seasons of the year, but most plentifully in the colder months. The pool was not more than a few

[Annals of Botany, Vol. XXIX. No. CXV. July, 1915.] 


\section{Griffiths.-On Glaucocystis Nostochinearum, Itzigsohn.}

inches deep and about twenty square yards in area. The soil was a red marl. A dense vegetation of Funcus communis, Alisma Plantago, and Ranunculus aquatilis nearly filled the pool. The occurrence of Glaucocystis in other than a Sphagnum-bog is not by any means a usual thing. No Sphagnzum is found in the immediate district.

\section{Collection and Fixation.}

Tufts of the Fontinalis were pulled up and the water was squeezed out into glass tubes. Subsequently the sediment, consisting of decayed vegetable matter, filamentous Cyanophyceae, a few Desmids, Bacillarieae, and Glaucocystis, was fixed either in a $2 \frac{1}{2}$ per cent. solution of formic aldehyde, or in a mixture of three parts absolute alcohol and one part glacial acetic acid. One drop of sediment contained under favourable conditions as many as twenty specimens of Glaucocystis. It was not found possible to separate the organisms from the flocculent matter in which they were found. In order to facilitate the treatment of the sediment in the alcohols and staining reagents, a centrifuge was used to bring the material down quickly to the bottom of the tube.

\section{STAINING REAGENTS.}

For staining the chromoplast, safranin and fuchsin were found to be the best. For the structure of the nucleus, haematoxylin and gentian violet were most successful. Iron alum and haematoxylin proved fairly satisfactory also. In all cases the sediment was taken up through the alcohols into xylol, and mounted finally in Canada Balsam for examination.

\section{The Cell-Wall.}

The cell-wall of Glaucocystis strikingly resembles that of Oocystis. The cell is ellipsoidal in shape and has apical thickenings on the inner side of the cell-wall. In addition, however, there is an equatorial thickening on the outer side of the cell-wall. The wall is fairly thick, but when in the mother-cell condition it becomes very thin and ultimately ruptures. When treated with iodine in potassium iodide and strong sulphuric acid the cell-wall turns blue. It consists, therefore, very largely of cellulose. In this respect the cell-wall of Glaucocystis differs from that of most Cyanophyceae.

\section{THE Chromatophores.}

These are of very remarkable form. Hieronymus ('92) describes and figures a series of radiating, strongly curved chromatophores from twelve to twenty in number, and of a blue-green colour. When the cell is about to divide, these chromatophores break up into a large number of oval plastids. After cell-division the chromatophores are re-formed. I made 
regular monthly collections of Glancocystis from the pool throughout I9I3, and at frequent intervals between 1910 and 1913 , but almost all the specimens found were in the division stage of the chromatophores. In only a few cases were the radiating bands seen. The unusual situation in which the organisms were found may be correlated with this. The usual habit is in Sphagnum-bogs, and in such places the chromatophores frequently show the structure described by Hieronymus. The colouring matter in the chromatophores consists largely of phycocyanin. In one case some specimens had been allowed to become unhealthy through long keeping in a tube. The phycocyanin came out of the plastids and filled the cell-sap with the characteristic blue colour.

\section{The Cytoplasm.}

This consists of a reticulum with granular threads. The size of the alveoli varies from I to $2 \mu$. The cytoplasm fills the cell completely and does not contain a central vacuole. On division of the cell, the cytoplasm constricts slightly in the equatorial plane, but the complete division takes place by a rectilinear fission transverse to the axis of the cell. In this respect Glaucocystis resembles many other Cyanophyceae, more especially the Chroococcaceae. The preliminary slight constriction of the cytoplasm does not seem to be correlated directly with the phases of nuclear division, but may occur either before or after. The final transverse fission takes place after nuclear division and is very rapid. The two parts of the cytoplasm round off into oval masses and daughter cell-walls are formed.

\section{The Nucleus and Nuclear Division.}

The nucleus, both in structure and in its division stages, shows many features of a remarkable kind. At one stage it bears a striking resemblance to the nucleus of higher plants. In another stage it appears to be little more than a vacuole. The following phases may be observed :

(a) A large round space $I I \mu$ in diameter lies in the equatorial portion of the cytoplasm, but close to the cell-wall. It stains very feebly indeed (Pl. XIX, Fig. I). The surrounding cytoplasm also stains feebly, but it is full of small oval and round bodies which stain deeply. None of these deeply staining bodies are to be found immediately between the clear space and the wall of the cell. The clear space does not possess a membrane, but is simply a space free from staining bodies. It appears to be continuous with the cytoplasm, and is not a vacuole. Under moderately great magnification it certainly does look like a vacuole, but under high magnification it is seen to consist of the same extremely delicate reticulum as the cytoplasm. The boundary of the clear space is not perfectly regular, but only approximately spherical owing to the slight intrusion of the staining bodies on its extreme 


\section{Griffiths.-On Glaucocystis Nostochinearum, Itzigsohn.}

outer edge. The deeply staining bodies in the cytoplasm lie at the intersection of the threads of the reticulum. The threads are very delicate and not granular at this stage.

(b) The clear space, which may be denoted the 'karyoplasmic area', now begins to contract and to move towards the centre of the cell. It becomes more deeply stainable, the staining being diffuse. Its reticulum, previously extremely delicate and difficult to see, becomes coarser and more visible. At the same time, the number of darkly staining bodies in the cytoplasm diminishes, and the whole cytoplasm becomes diffusely stainable. The karyoplasmic area does not possess a definite membrane at this stage (Fig. 2).

(c) The karyoplasmic area contracts further until it reaches a diameter of 6 or $7 \mu$, and a well-marked membrane forms. The cell as a whole increases in size also. The threads of the karyoplasmic reticulum become thick and stain more deeply. Deeply staining granules of chromatin appear at the intersections of the threads (Fig. 3). One granule becomes very much larger than the rest. It is circular or roughly polyhedral in outline. It is not homogeneous in structure, but is composed of many granules fused together. The dark bodies of the cytoplasm disappear completely, and the threads of the cytoplasmic reticulum become finely granular. These granulations do not stain deeply (Fig. 4). At this stage, the cell bears a striking resemblance to the cell of higher plants. There is a definite nucleus bounded by a membrane, and possessing darkly staining granules of chromatin. The large karyosome, roughly circular in form, resembles a nucleolus in position, but, as will be seen later, its behaviour is quite different from that of the nucleolus of higher plants.

(d) The concentration and definition of the nucleus is a preparation for division. The nucleus elongates to a length of about I I $\mu$, but the diameter remains about the same (Fig. 5). The nucleolus-like karyosome becomes a very conspicuous object. It grows very large, probably by the addition of the smaller granules of chromatin previously scattered on the nuclear reticulum. The nuclear reticulum itself ceases to be visible, and the nucleus becomes uniformly diffusely stainable, with the large karyosome lying in it. The karyosome now divides by a transverse fission into two equal parts semicircular in outline, which separate a short distance. . No case was observed among the very large number of dividing nuclei in which there was anything in the nature of a polar separation of chromatin substance or the formation of a chromatic figure. In every instance the process consisted of the aggregation of chromatic material into a large karyosome, which subsequently divided by simple transverse fission. After the division of the karyosome, the nucleus divides in a precisely similar manner (Figs. 6 and 8). A large number of specimens were in this stage. Each half of the nucleus is semicircular or semi-elliptical, with a very distinct 
straight edge along the line of fission. Sometimes the half-nucleus has one or more pointed processes (Figs. 8 and 9). These always lie on a line radiating from the karyosome towards the line of transverse fission. In some cases, numerous radiating lines of strain were found traversing the whole cytoplasm. Their centre of convergence lies at the karyosome, and they do not appear to cross the line of transverse fission of the cytoplasm (Fig. 8). The cytoplasm may show signs of division even before the division of the nucleus is initiated. On the other hand, it may be delayed until after. A distinct constriction appears in the equatorial plane. This is followed by a straight transverse fission which is always delayed until the nucleus has divided. After this, the cytoplasm rapidly rounds off, each halfnucleus becomes spherical, and two daughter cell-walls are formed (Fig. Io). In some cases the nucleus divides into four (Fig. II), or even into eight (Figs. I2 and 14), and four or eight daughter-cells are formed simultaneously. In other cases two or four daughter-cells are formed, and a second nuclear division takes place (Fig. I 5). Previous to the formation of daughter-cells, the mother-cell increases greatly in size. In the resting condition the cell measures about $30 \mu$ by $18 \mu$. During division it may attain a size of $45 \mu$ by $25 \mu$, that is, it about doubles in volume. The daughter-cells are therefore about normal size. In this increase in size before division Glaucocystis differs altogether from Oocystis. Bohlin ('97) records that G. cingulata also varies greatly in size, the diameter varying from 12 to $56 \mu$, and the length from 16 to $5^{6} \mu$.

(e) Division having taken place and the daughter-cells having been formed, the nucleus of each begins to undergo a series of degradations. The karyosome, that played so important a part in cell-division, breaks up. The stainable nuclear reticulum disappears, and the nuclear membrane can no longer be seen. The cytoplasm once more becomes full of deeply staining granules, and the karyoplasmic area less definite and more feebly stainable. Ultimately the cell reaches the resting condition described in the first section. The nucleus is now represented by the vacuole-like karyoplasmic area, and ceases to resemble the nucleus of higher plants. The chromoplast, which had broken up into numerous oval plastids during the stages of cell-division, reorganizes, and becomes once more a series of radiating recurved bands.

\section{COMPARISON WITH OTHER FORMS.}

The nucleus of the Myxophyceae is characterized by its irregular form, the absence of a nuclear membrane, the absence of a nucleolus, and by a tendency for cell-division to take place independently of nuclear division. Chromatin is present, and Kohl ('O3) and Hegler have observed the formation of a chromatic figure. Wager ('01) also states that owing to the drawing out of the chromatin threads elongated cells often show stages

$$
\text { F f } 2
$$




\section{Griffiths.-.On Glaucocystis Nostochinearum, Itzigsohn.}

resembling true karyokinetic division. Darkly staining granules in the cytoplasm have been recorded under the names of central granules, metachromatin, and volutin, and their gradual disappearance by diffusion has been noted (Guilliermond ('12), Minchin ('12)).

Miss Acton ('14) has described the nucleus of Chroococcus. In C. macrococcus it is confined to a definite area, and is more or less oval in form. It contains chromatin, but has no nuclear membrane or nucleolus. It divides by simple transverse fission. In other species the nucleus is of the 'open' type. In Merismopedia elegans no nucleus is present in certain stages, but later on granules of metachromatin appear in the cytoplasm, followed by the formation of a deeper staining nuclear area. The latter develops darkly staining granules, while the metachromatin disappears from the cytoplasm. The nucleus divides, apparently by a transverse fission, and subsequently degrades and disappears. The cytoplasm commences to constrict before actual nuclear division, and the final division is completed after the division of the nucleus.

The cytology of Glaucocystis shows a more highly elaborated nuclear structure than any other member of the Cyanophyceae, but nevertheless it is only a difference in degree and not in kind. In stage (a) described above, the nucleus is apparently of the 'open' type. One might say that the karyoplasmic area is only potentially a nucleus. It is continuous with the rest of the cell protoplasm and devoid of stainable material. It is only distinguished from the general protoplasm by the marked absence of the comparatively large granules of metachromatin. The area is not perfectly definite, and is not bounded by a membrane. It is not in any way a vacuole. In this stage it is comparable with the 'open' nuclei of many of the Hormogoniae, except that it is of very regular form.

In stage $(b)$ the karyoplasmic area moves to the centre of the cell and diminishes in size. The metachromatin granules of the cytoplasm diminish in number. At the same time the nuclear area, although without signs of a stainable reticulum, is diffusely stainable as a whole. It seems that the metachromatic substance is being taken into the nuclear areas in a diffuse form. Similar diffusion of metachromatin has been noted in other cases by Acton ('14), by Wager and Peniston ('10), and by Lutman ('11).

In stage $(c)$ the nucleus has contracted to its smallest size. A karyoplasmic reticulum of thicker threads has developed. This stains deeply, probably owing to minute granules of chromatin in the threads. At the intersection of the threads larger chromatin grains are seen. With haematoxylin these grains take a dull dark red colour. They seem to be solid. The metachromatin grains of the cytoplasm are coloured a bright purple-red, and appear to be translucent. By this time all the metachromatin has disappeared from the cytoplasm. The cytoplasmic reticulum consists of granular threads. At this stage, therefore, the cell structure resembles that 
of Chroococcus macrococcus, or of Merismopedia elegans in its stage preparatory to division. Glaucocystis, however, shows a more elaborate structure in two ways, first in the possession of a definite nuclear membrane, and secondly in the formation of the very large mass of chromatin resembling a nucleolus in position, which $I$ have referred to as the 'large karyosome'.

In stage $(d)$ the behaviour of the nucleus is different from any other of the Cyanophyceae. The large karyosome gradually attains a considerable size by drawing to itself all, or nearly all, the chromatin of the nucleus. Nuclear division is initiated by the transverse fission of the karyosome, and is completed by a similar division of the nucleus. This division is shared in by the whole cell. The cytoplasm shows strain lines radiating from the two karyosomes in some cases. Similar phenomena have been observed in Lyngbya (Brown, '11). Although the cytoplasm shows at first the Myxophycean character of division independent of the nucleus, it waits until nuclear division is complete before completing its transverse fission. This transverse fission is exhibited by such forms as Chroococcus macrococcus and Merismopedia elegans, but their nuclei remain in the stage of the simple chromatin reticulum, and there is no sign of the aggregation of chromatin material for purposes of equal division. In this respect Glaucocystis appears to have evolved a rough process of chromatin distribution comparable with the karyokinesis of high plants. The karyosome would be, according to this view, rather of the nature of a chromosome than of a nucleolus.

The organism shows also a higher specialization in its formation of daughter-cells. Alone among the Cyanophyceae, it produces daughtercells similar in outward form to those of the mother-cell and within the mother-cell wall (as in Oocystis). There is, however, a profound difference, as the mother-cell of Glaucocystis nearly doubles in volume before dividing, whereas in Oocystis this is not the case.

In stage $(e)$ the nucleus has finished its work of division and proceeds to take to pieces the structure it had elaborated. The large chromatin karyosome breaks up, the nuclear reticulum disappears, and once more the brilliantly staining metachromatin granules appear in the cytoplasm. The nuclear area increases in size, moves towards the side of the cell, and assumes the clear vacuole-like state of the resting condition.

Glaucocystis shows, therefore, a near approach to the cytological structure of higher plant cells, both in its actual nucleus and in the formation of daughter-cells. In higher plants the elaborate structure of the nucleus is retained permanently, but in this organism the nucleus reverts to the 'open ' condition, and for each division must reconstruct itself.

That Glaucocystis is one of the Cyanophyceae is shown by the following characters : (1) The nucleus is of the 'open' type at one stage. (2) Nuclear division takes place by transverse fission, and the division of the cytoplasm 


\section{Griffiths.-On Glaucocystis Nostochinearum, Itzigsohn.}

shows a distinct tendency to be independent of the division of the karyoplasm. (3) Phycocyanin is present as the colouring substance.

It differs from most Cyanophyceae in the following particulars: (1) The nucleus preparatory to division becomes 'closed'. It has a membrane and a nuclear reticulum possessing chromatin. The chromatin is aggregated into a single mass which divides by transverse fission. (2) After division of the cytoplasm, the two parts become rounded off and daughtercells are formed, very similar to those of Oocystis. (3) The cell-wall consists very largely of cellulose. (4) There is a definite and elaborate chromoplast.

\section{SUMMARY.}

Glaucocystis Nostochinearum, Itzigsohn, is a unicellular solitary alga found generally in Sphagnum-bogs. It is ellipsoidal, and measures from 30 to $45 \mu$ in length, and from 18 to $25 \mu$ in breadth. It has a small internal polar thickening of the cell-wall at each end, and an equatorial external thickening. The cell-wall is composed mainly of cellulose. There is a definite chromoplast consisting of a number of strongly recurved and radiating bands of a blue-green colour. These break up into numerous short pieces in the division stage of the cell. The organism reproduces by the formation of two, four, or eight daughter-cells lying freely within the mother-cell wall.

In the resting stage the nucleus is of the 'open' type. It consists of a large colourless spherical portion of the delicate reticulate protoplasm, and is practically unstainable. It is only distinguished from the general cytoplasm by the complete absence of the metachromatin granules. This portion lies close against the cell-wall.

In the division stage, the nuclear portion of the protoplasm contracts, becomes coarsely reticulate, moves to the centre of the cell, and becomes stainable. Chromatin develops in this reticulum, and a nuclear membrane forms. The metachromatin granules of the cytoplasm gradually disappear. The chromatin of the nucleus aggregates into a large karyosome. This divides by transverse fission, and each part rounds off. The cytoplasm divides by transverse fission, each half rounds off, and daughter-cell walls are formed.

Glaucocystis is probably a member of the Cyanophyceae owing to the presence of an 'open' nucleus at one stage ; the tendency of cytoplasmic division to take place independently of nuclear division; and to the presence of phycocyanin in the chromoplast. The very high differentiation of the nucleus in the dividing stage; the elaborate chromoplast to which the phycocyanin is confined; the formation of daughter-cells very similar to those of Oocystis; and the cellulose character of the cell-wall, are features 
Griffiths.-On Glaucocystis Nostochinearum, Itzigsohn. $43 \mathrm{I}$

which separate Glaucocystis from all the rest of the Cyanophyceae, and probably justify it being placed in an entirely separate group of that division.

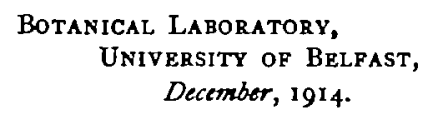

\section{LITERATURE.}

Acton, Miss E. (14): Observations on the Cytology of the Chroococcacene. Ann. of Bot, vol. Irviii, 1914

Bohlin, K. ('97): Die Algen der ersten regnell'schen Expedition. Stockholm, 1897, pp. I3, I4.

Brown, W. H. ('11) : Cell Division in Lyngbya. Bot. Gaz., vol. li, I9r I.

Gunliermond, A. ('12): A propos des corpuscules métachromatiques, on grains de volutins. Archiv f. Protistenkande, vol. xix, p. 289 et seq.

Hikronymus, G. (82) : Cohn's Beitr. z. Biol. d. Pfl., Breslau, 189a, p. $46 \mathrm{r}$.

KoHL ('08) : Ueber dic Organisation und Physiologie der Cyanophy., und die mitot. Teilung ihres Kernes. Jena, igo3.

Lutman, B. F. ('11): Cell and Nuclear Division in Closterium. Bot. Gax, vol. li, June igr I.

Minchin, E. A. ('12): An Introduction to the Stndy of the Protozoa. Landon, 1912, p. 65.

Oltmanns, F. ('04): Morphologie und Biologie der Algen. Jena, I904, p. IgI.

WAGER, H. ('88) : The Nucleus of the Yeast Plant. Ann. of Bot., vol. xii, 1898.

('01): Report to Brit. Assoc., I90I (1902).

(04): Nuclear Division in Root Apex of Phaseolus. Ann. of Bot., vol. xvili, 1904

and Prniston, A. ('10). Cytological Observations on Yeast Plant. Ann, of Bot., vol. xaiv, rgro.

West, G. S. ('04) : The British Freshwater Algae. 1904, pp. 316 and 317.

\section{DESCRIPTION OF PLATE XIX.}

Illustrating Mr. Griffths's paper on Glaucacystis Nostochinearw/m, Itzigsohn.

All drawings (except Fig. 12) were made with a Zeiss Abbé camera-lucida on a Zeiss microscope with achromatic objectives and compensated oculars. For finest details an oil-immersion 17 objective was ased. Diffuse staining is indicated by fine dots. The cell-wall is nut shown in many cases.

Fig. I. Glaucocystis Nostochinearum in resting condition. $\times 857 . \quad k$, kary'plasmic area; m., cytoplasm full of metachromatin granules.

Fig. 2. Cell with karyoplasmic area in centre. $\times 857$. e., equatorial thickeaing; $p$., polar thickening; other letters as before.

Fig. 3. Cell with definite nacleus. $\times 857$.

Fig. 4 Cell with definite nucleus. $\times 857$. l.k., large karyosome of chromatin,

Fig. 5. Cell with elongated nucleus. $\times 857$.

Fig. 6. Cell with nacleus in process of division by transverse fission. $\times 857$. The large karyosome has already divided. 


\section{Griffiths.-On Glaucocyslis Nostochinearum, Itzigsohn.}

Fig. 7. Cell with nacleas completely divided.

Fig. 8. Cell with divided nucleus, one half of which has a process. $\times 857$. In the cytoplasm are 'strain lines', radiating from the two half-nuclei.

Fig. 9. Cell with divided nucleos, each half with processes. $\times 8_{57}$.

Fig. 10. Mother-cell with two daughter-cells. $\times 545$.

Fig. II. Cell with nucleus divided directly into four. $\times 857$.

Fig. I2. Unhealthy cell with phycocyanin diffused in cell-sap. $\times 857$ approx. The protoplasm has divided into apparently seven, but possibly eight, portions. The nucleus has probably divided into eight in this case.

Fig. I3. Mother-cell with four daughter-cells. $\times 545$.

Fig. I4. Mother-cell with eight daughter-cells. $\times 545$.

Fig. I 5. Mother-cell with four danghter-cells. $\times$ 545. Each danghter-cell has andergone subsequent nuclear division, bat cytoplasmic division has not yet taken place. Several cases of two danghter-cells were observed in which a second nuclear division was taking place. 


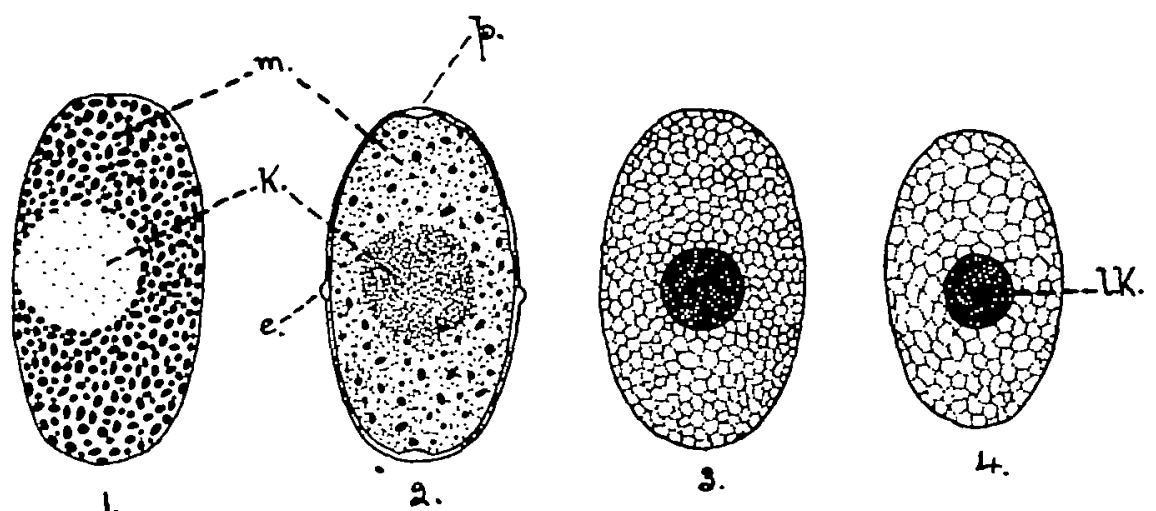

1.

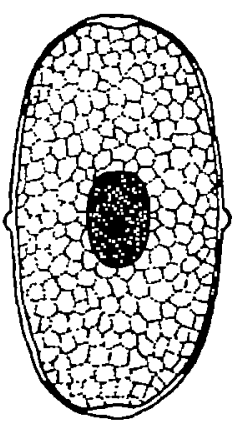

5.

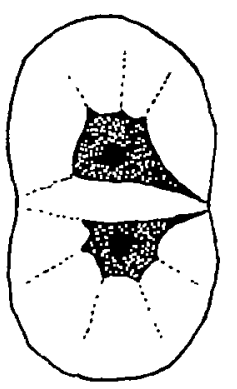

9.

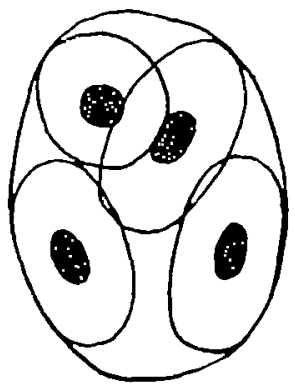

13

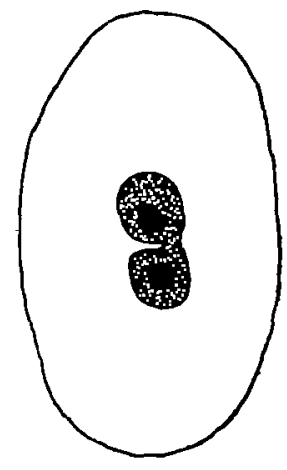

6.

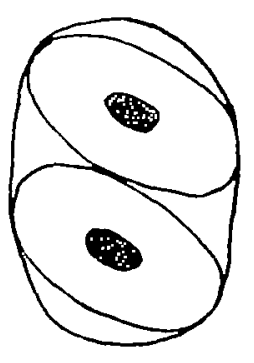

10.
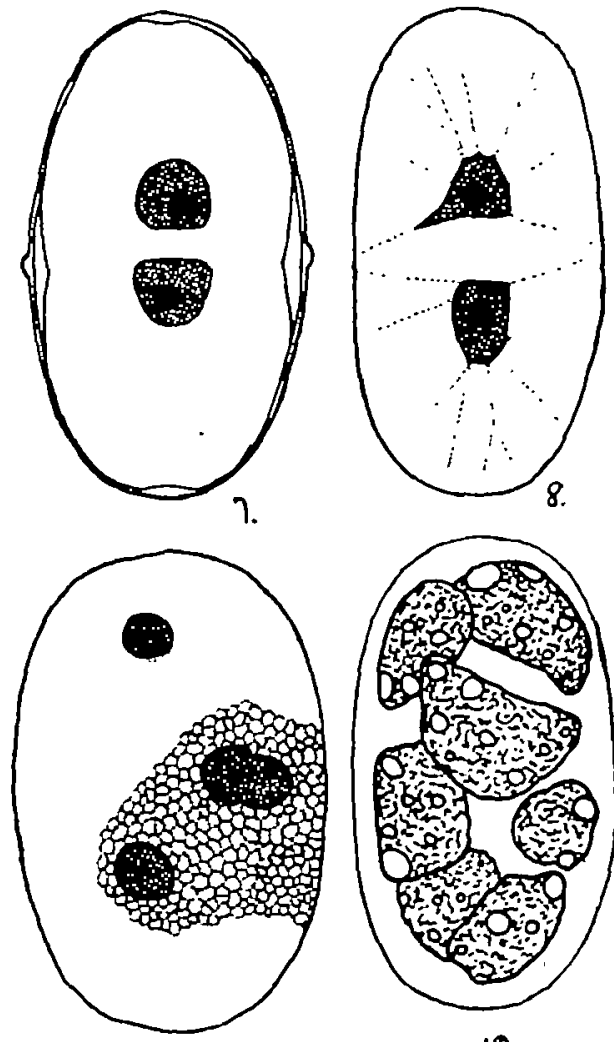

12.

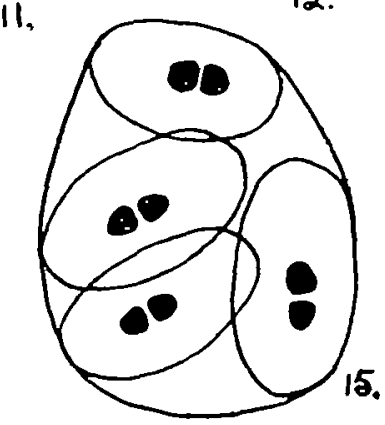

GRIFFITHS-GLAUCOCYSTIS NOSTOCHINEARUM, ITZIGS. 